Article

\title{
The Effects of Regulatory Capital Requirements and Ownership Structure on Bank Lending in Emerging Asian Markets
}

\author{
Yasmeen Akhtar ${ }^{1, *}$, Ghulam Mujtaba Kayani ${ }^{1}$ and Tahir Yousaf ${ }^{2}$ \\ 1 Department of Management Science, COMSATS University, Islamabad 44000, Pakistan \\ 2 Business School of Sichuan University, Chengdu 610207, China \\ * Correspondence: yasmeenakhtar02@yahoo.com; Tel.: +92-322-714-0501
}

Received: 29 July 2019; Accepted: 29 August 2019; Published: 9 September 2019

check for updates

\begin{abstract}
This study examines the impact of regulatory capital requirements and ownership structure on bank lending in Emerging Asian Markets. The findings of the study imply that banks with excess capital are less affected by capital constraints and enjoy opportunities to extend their credit portfolios. The monitory policy indicator has the expected negative and significant impact on bank lending. In case of well-capitalized banks, the interaction between the excess capital and monetary policy indicator has a significant positive relation with bank lending, which means that banks with excess capital have capability to raise uninsured financing and shield their loan portfolios as compared to less-capitalized banks that reduce their lending in the period of monetary tightening. In the case of bank ownership structure, banks with excess capital ratios and ownership concentration lead towards an increase in lending activity. The findings also show that well-capitalized banks with managerial ownership tend to reduce lending which validates agency theory of corporate governance.
\end{abstract}

Keywords: regulatory capital requirements; ownership structure; bank lending; monetary policy indicator; emerging Asian markets

\section{Introduction}

Capital and liquidity shortage in the international banking system has been exposed as a big threat to the stability of financial systems, particularly after the 2007 US sub-prime and 2009 European sovereign crises. Therefore, to improve the global financial system, Basel Committee on Banking Supervision (BCBS) proposed Basel III to change the banking system regulations in terms of capital, liquidity and credit risk (Tanda 2015). Basel III was introduced in 2010 and has increased the capital requirements in terms of risk weighted assets but its economic implications up to this point are still not clear. Banks may increase their capital ratios either through improving their capital levels or by decreasing their risk weighted assets (Admati et al. 2018). Increase in the capital is considered by regulators as 'good deleveraging' while reduction in risk weighted assets has a potential adverse impact if banks simultaneously involve in cutting their lending activity, i.e., to reduce the corporate and consumer lending (Majcher 2015). Thus, the question of how banks adjust their lending activity in response to new capital requirements is a crucial one to understand its actual implications. Therefore, the current study identifies this problem as one of its objectives and attempts to answer the question of how banks respond to these regulatory capital requirements.

The investigation of the relationship between regulatory capital and bank lending is a major issue discussed in previous literature, that either focus their direct association (Fang et al. 2018; Plosser and Santos 2018) or indirect relation through economic or bank-specific characteristics. The economic features include the monetary policy indicator that is explained by conventional bank-lending channel 
that how bank capital influences the lending activity under assumption of imperfect debt markets. Particularly, bank equity affects the ability of banks to issue uninsured form of debt and consequently contain the effect of deposit fall on lending through the following mechanism. Reservable deposits drop, subsequent to a monetary contraction, and banks issue nonreservable debt in order to defend their lending portfolios. The nonreservable financing is usually uninsured (i.e., CDs or bonds) and banks face problems in fund issuance and suffer from adverse selection. Hence, banks have little capacity to protect their credit relations and less-capitalized banks are recognized by market more risky as compared to banks with excess capital (Dwarkasing et al. 2017; Gambacorta and Mistrulli 2004; Salachas et al. 2017; Heryán and Tzeremes 2017; Xiong 2013; Plosser and Santos 2018).

Economic features also include the output (i.e., GDP) indicators. Bank capital effects the lending through output indicators and the impact depends on the relationship between bank capital and risk-aversion behavior. On one side, it is argued that well-capitalized banks react less to output shocks as compared to less-capitalized banks because they hold excess capital and need little adjustment in lending during economic downfalls and also their profits are less sensitive to business cycles. On the other side, well-capitalized banks are considered more risk-averse because they have a portfolio of borrowers, ex ante, who are less financially fragile and thus limiting banks' exposure to default risk when an economic downturn occurs (Gambacorta and Mistrulli 2004). The other strand of studies examine the supposition that the impact of bank equity on lending varies depending on other bank related features, specified that this impact varies depending on level of equity itself (Berrospide and Edge 2010; Cornett et al. 2011; Ivashina and Scharfstein 2010).

Because of the crises faced in the last three decades, banking sector activities have been reformed by introducing new business forms to the traditional intermediation roles. These reforms result into consolidation of banking industry and change in ownership patterns especially in the form of increased institutional ownership that leads towards the change in bank risk-taking attitude and ultimately in its lending activity (Barry et al. 2011). Also the separation of ownership and management lead towards agency problems in corporate banking sector. Gorton and Rosen (1995) document that entrench managers are inclined to take on further risk rather than less in a damaged banking system that is subject to moral hazard problem. In an environment of increased competition, managers who have better information regarding portfolio quality might have greater chances to pursue a relaxed strategy than the other stakeholders, who are expected to be extremely risky ex-post.

The previous literature either considers the direct impact of ownership structure on bank lending or indirect effect depending on type of financial crisis (Allen et al. 2017; Coleman and Feler 2015; Berger and Sedunov 2017) or it considers the impact of ownership structure and regulatory environment on bank lending corruption (Barry et al. 2016). There are no studies, however, that have examined the joint impact of capital regulation and ownership structure on bank lending activity and whether the findings can be generalized beyond the US and Europe, where most of the previous studies are conducted. The debate on the ownership structure in banking sector is of the paramount importance because various factors interact with and alter the ownership pattern like bank capital regulations, supervision mechanisms and opacity of banking industry assets. The motivation behind the current study is that we employ the ownership structure as a determinant of bank lending activity and consider its moderating role, by including interaction term between bank capital and ownership structure.

The current study contributes to literature in several ways. First, we examine the direct impact of regulatory capital requirements on bank lending and also consider its indirect role. The indirect impact is captured through the economic features and against bank related features like bank size and liquidity. Second, we employ the bank ownership structure as a determinant of lending activity and also consider its moderating role. We want to examine how the relation between regulatory capital and bank lending changes under diverse ownership structures. This is the first study, to our knowledge, that consider the joint impact of regulatory capital and ownership structure on bank lending. Third, Basel III is introduced in reaction to a financial crisis that mainly prevailed in western economies but the regulations are introduced not only to counter the reasons behind crisis but also to eliminate the 
gaps in regulatory standards throughout the world. However, it is later revealed that these regulations are mainly aimed for advanced economies and emerging market needs are ignored. Then the question that 'Is Basel III bad news for emerging market economies?' matters because advanced and emerging markets have divergent risk preferences. In case of advanced economies the purpose of Basel III is to avoid the episode of crisis, but in emerging markets the main concern is growth, i.e., to tackle the rapidly growing population needs (Sheng 2013). Then, there is a need of paramount importance for the proper balance between the conservation of Asian region growth impetus and the continuous power of its financial structure. Most of the previous studies, related to Basel regulatory requirements, focus on western economies like US and Europe, and studies related to the Asian economy are limited or far from conclusive. Consequently, Asian emerging economy provides an attractive place for investigation of the implications of Basel regulatory capital requirements in the present era.

The study findings show that banks with excess capital are less effected by capital constraints and enjoy opportunities to extend their credit portfolios. The monetary policy indicator has the expected negative and significant impact on bank lending but the banks with excess capital have ability to raise uninsured form of financing and therefore shield their loan portfolios in period of monetary tightening. In the case of bank ownership models, results show that banks with excess capital and ownership concentration lead towards an increase in lending activity. The finding also implies that well-capitalized banks with managerial ownership tend to reduce lending which validates the agency theory of corporate governance that management act for their own interests as compared to other stakeholders' and owners' interests.

The remainder of the study is organized in the following sections. Section 2 contains the Literature review and hypothesis development. Section 3 comprises sample selection and data description. The fourth section presents the empirical methods and econometric model. Results and discussion are given in Section 5 and final section concludes the study.

\section{Literature Review}

The section deals with academic literature regarding presence (or absence) of the credit crisis provoked by the implementation of Basel capital accord. Regulatory capital requirements can influence the banking system capacity to expand credit. If regulatory capital level is set excessively higher (i.e., beyond economic needs of capital), in that case risk-adjusted market returns on bank loans will not be enough to cover the artificially higher capital cost, thus decreasing bank credit creation activity. So, the cumulative economic activity is influenced by this so-called credit crunch.

\subsection{Regulatory Capital Requirements and Bank Lending}

Previous studies regarding the effect of regulatory capital requirements on credit availability either focus their direct relation or indirect relation through economic or bank specific characteristics. Gambacorta and Mistrulli (2004) investigate the presence of cross-section changes in lending, in reaction to monetary policy and output shocks, with reference to difference in bank capital. The study results indicate that banks with excess capital may better protect their lending in reaction to monetary policy indicator as they have an easy access to uninsured form of debt, consistent with 'bank-lending channel' proposition. Capital also influences the manner in which banks respond to output shocks: well-capitalized banks can better absorb short-term financial problems on behalf of debtors and maintain long-run lending relations. Berrospide and Edge (2010) findings show the modest effect of bank capital change on lending. The nonlinearity tests and interaction term effects with output shocks are also being analyzed but not proved to be significant in any case.

In comparison to previous studies, Gambacorta and Marques-Ibanez (2011) document that standard bank specific feature, normally included in literature (size, capitalization, liquidity etc.), are unable to completely capture the working of bank-lending channel new dimensions. Firstly, the findings of study show that the quantity of short-run financing and securitization seems to be essential in the way banks respond to monetary policy shocks. The findings also show that a prolonged era of 
down interest rates may enhance lending that is consistent with bank "risk taking channel" proposition. Finally, study results do not identify major deviations in normal effect of monetary shock on credit during periods of economic crisis. Cornett et al. (2011) study how banks handle liquidity crisis that prevail throughout 2007 financial crisis, also how they attempts to sustain loan availability. The study results show that banks that mainly rely on core deposits and capital financing carry on their lending. Banks which hold less liquid assets on balance sheet, in comparison, improve assets liquidity and decrease lending.

Carlson, Shan, and Warusawitharana (Carlson et al. 2013) investigate the impact of bank capital on lending by valuing variations in loan growth to differences in capital level. The study provides evidence that, all else being equal, banks with relatively higher real capital ratios have strong loan growth during financial crisis of 2008 to 2010, but there is no clear relationship in prior years. The findings also show that impact of bank capital on loan growth is nonlinear. Xiong (2013) focuses on role of bank-lending channel in monetary policy transmission mechanism in China. The study results suggest that central banks' monetary policies unevenly affect bank lending behavior. Well-capitalized banks appear to probably amend more their lending behavior in reaction to expansionary policy, and on the other hand, banks with low-capitalization tend to change with initiation of tight monetary policy.

Nicolò (2015) revisits the matter by reviewing latest literature and offers new evidence with worldwide data sets at firm and state level. The results of the study propose that negative impact of the increase in bank capital requirements on lending and real economic activity is notably larger than in earlier studies both in the short and long run. Hamada (2017) examines the impact of bank-lending channel in the Indonesian banking segment and investigates the effects of monetary policy shocks on lending through bank capital levels. The findings of the study show that well-capitalized banks raise their provisions of loans, but non-forex banks still not react against monetary policy. Aysan, Disli, and Ozturk (Aysan et al. 2017) focus on change in deposits and credit behavior in conventional and Islamic banks in reaction to monetary shocks. The findings support the presence of bank-lending channel in Turkey. It is, however, observed that reactions of deposit and credit to monetary shocks are larger in Islamic banks' case. The study finds comparable findings vies- a-vies lending activities, specifying that demand of credit is more influenced in case of Islamic banks subsequent to changes in policy rate.

Bank liquidity also plays a role in examining the relation between regulatory capital and credit crunch. The hypothesis that 'The impact of bank equity on credit supply is directly related to the liquidity level of the bank' points to the fact that bank capital impact on lending shows a rising slope depending on liquidity level; in another way, we anticipate that banks with high level of liquid asset are likely to provide more credit subsequent to increase in equity than the banks with low level of liquid asset. This forecast is consistent among previous researches arguing that low liquidity banks are expected to cut loans to sustain their holdings of liquid assets above a severely low position (Berrospide and Edge 2010; Cornett et al. 2011; Kashyap and Stein 2000).

The above proposition can also be described based on two strands of theories on relation between bank equity and liquidity formation, 'financial-fragility/crowding-out' and 'risk-absorption' hypotheses, given by Berger and Bouwman (2009). The 'financial-fragility/crowding-out' proposition forecasts that impact of bank equity on credit availability is negative as capital investors, unlike depositors, cannot run on banks and are unwilling to supply loans. On the contrary, the impact of bank equity on credit availability is positive according to 'risk-absorption' hypothesis because bank equity improves the risk-bearing capability of banks. Kim and Sohn (2017) document that 'financial fragility/crowding out' impact takes over 'risk absorption' impact once banks have not enough liquidity. Though, once banks build up enough liquidity, it is expected that equity holders become less unwilling to provide credit and increase in bank equity develops bank risk absorption ability extensively. The result suggests that impact of rise in bank capital on loan growth is notably negative for low liquidity levels, becoming radically positive merely after big banks maintain enough liquid assets. On the basis of previous academic literature we test the following hypothesis: 
Hypothesis 1 (H1). There is a direct impact of regulatory capital requirements on bank credit availability.

Hypothesis 2 (H2). The effect of regulatory capital requirements on bank credit is associated with monetary policy indicator.

Hypothesis 3 (H3). The effect of bank capital requirements on lending is associated with output indicator.

Hypothesis 4 (H4). The effect of bank capital requirements on lending is associated with bank-specific characteristics.

\subsection{Ownership Structure and Bank Lending}

In this section we discuss the association between ownership structure and bank lending and also the joint impact of capital requirements and ownership structure on bank lending. Earlier, foreign banks entry is thought to be a positive sign for CEE (Central Eastern and European) region because prior empirical literature proves that foreign banks entry brings more efficiency in banking industry (Bonin et al. 2005; Fries and Taci 2005). A cross-country analysis by Clarke et al. (2006) show that companies in regions with higher level of foreign banks involvement consider the long-term loan access and interest rates as weak constraints on their growth and operation than the companies in regions with low or modest presence of foreign banks.

However, numerous latest studies show that foreign ownership banks reduce the credit supply during financial crisis of 2008 in CEE region. Allen et al. (2017) examine the relationship between bank lending activities, ownership structure, and crisis situations by using a sample of 400 banks during period of 1994-2010 in CEE region. The results of study show that the impact of ownership structure on lending depends on the type of crisis i.e., whether it is a home, host, or worldwide or simultaneous crisis. Cull and Peria (2013) also show that foreign-owned banks credit growth decrease more than the private domestic banks. They also document that state-owned banks credit growth exceeded as compared to foreign and domestic ownership banks during a crisis in Latin America. However, the study does not provide any evidence regarding state-owned banks credit growth as compared to private-owned banks. Haas et al. (2015), by using a large dataset, find weak support that state-owned banks reduce lending less as compared to private-owned banks in CEE region in 2009. The study documents that some states used government banks to smooth the aggregate level of lending while private banks started to deleverage. Barry, Lepetita, and Strobel (Barry et al. 2016) analyze the impact of ownership structure, regulatory environment, and economic development on lending corruption in banks of both the developed and developing countries. The findings show that lending corruption is high when large percentage of loans are provided to economy by state ownership and family ownership banks. The strong regulations lead towards reduced corruption in case of family ownership banks.

By reviewing previous academic literature, the current study finds a gap on the joint impact of regulatory capital and ownership structure on bank lending. So, the present study contributes to existing literature that it not only considers the direct impact of ownership structure but also examines its moderating role in influencing lending activity through regulatory capital. This is the first study, to our knowledge, which investigates the impact of bank ownership structure on credit supply depending on regulatory capital ratios. On the basis of previous literature we test the following hypothesis:

Hypothesis 5 (H5). The effect of bank capital requirements on lending is associated with bank ownership structure. 


\section{Sample Selection and Variable Description}

\subsection{Sample Selection}

The current study used the FTSE (Financial Times Stock Exchange) Russell country classification of markets and MSCI (Morgan Stanley Capital International) emerging market index for sample selection. A recognized provisional review of country categorization within FTSE global equity indexes is carried out every March by using a broad, transparent, and reliable method to keep investors informed fully about markets that have been placed on Watch List the preceding September. The MSCI Emerging Markets Index is used to quantify the performance of equity market in emerging global markets. Thus, the selected sample includes the Asian Emerging markets that are the part of both index i.e., FTSE Russell index and MSCI emerging market index.

The final sample includes the seven Asian emerging markets comprising China, India, Pakistan, Indonesia, Malaysia, Thailand, and Philippines. The sample includes the listed commercial banks on the national exchanges and data range from 2004-2017 and we include the banks which have (1) consecutive ten or more years data available, (2) regulatory capital ratios data available (3), lending data available (i.e., the dependent variable in the model), (4) as most of the banks have ownership data available from 2007 onwards, so the ownership model data ranges from 2007-2017.

The present study examines the bank-level panel dataset encompassing the seven Asian emerging markets. The actual data sources are the sample countries bank annual reports and S\&P Capital IQ database. The financial and regulatory capital data is collected from S\&P Capital IQ database and ownership data is collected from relevant countries bank annual reports. The macroeconomic data is collected from World Development Indicator and International Monetary Fund. The detail of the Dependent and independent variables used in study is given in Table 1.

Table 1. Variables Description.

\begin{tabular}{|c|c|c|}
\hline Classification & Variables & Description \\
\hline Dependent Variable & Bank Loans (Loans) & Annual growth rate of natural log of Bank Loans \\
\hline \multirow{4}{*}{ Independent Variables } & Monitory policy indicator (MP) & $\begin{array}{c}\text { Monetary policy indicator is central bank policy rate } \\
\text { of the Banks and other credit institutes }\end{array}$ \\
\hline & Economic growth (GDP) & Real GDP growth ratio \\
\hline & Inflation rate (INF) & Measured by Consumer Price Index \\
\hline & Excess capital of banks (EXCAP) & Regulatory capital minus capital requirements ${ }^{1}$ \\
\hline \multirow{3}{*}{ Control Variables } & Liquidity (LIQ) & $\begin{array}{l}\text { Calculated as total of cash and marketable securities } \\
\text { to total assets }\end{array}$ \\
\hline & Size (SIZE) & Calculated as log of total assets \\
\hline & $\begin{array}{l}\text { Non-performing loans ratio } \\
\text { (NPLR) }\end{array}$ & Non-performing loans to total loan \\
\hline \multirow{4}{*}{ Ownership Variables (OWN) } & \multirow{2}{*}{ Ownership Concentration (OC) } & $\begin{array}{l}\% \text { of shares held by top three shareholders who hold } \\
\text { greater than or equal to } 10 \% \text { of shares (OC10). }\end{array}$ \\
\hline & & $\begin{array}{l}\% \text { of shares held by top five shareholders who hold } \\
\text { greater than or equal to } 5 \% \text { of shares (OC5). }\end{array}$ \\
\hline & Managerial Ownership (MO) & $\%$ of shares held by management and directors \\
\hline & Foreign Ownership (FO) & $\%$ of shares held by foreign entities \\
\hline
\end{tabular}

1 The excess capital measure is calculated by taking the difference of banks' regulatory capital ratio and the minimum capital requirements under Basel III (i.e., $8 \%$ ). We take the conservative measure of capital ratio as regulatory capital, defined as tier 1 ratio, which includes the stock issues, provisions and reserves for general bank risks.

\subsection{Variables Description}

The current study examines the impact of regulatory capital requirements and ownership structure on bank lending in case of Asian emerging economies. The study employs the annual growth rate of bank loans as a dependent variable. The independent variables include a measure of bank excess capital, ownership variables and control variables. The detail of the variables used in study is given in Table 1. 


\section{Empirical Methods and Model}

The current study employs Arellano and Bond (1991) two step dynamic panel technique because of the possibility of endogeniety problem. Dynamic panel techniques incorporate the endogeniety in model by instrumental variables approach. This endogenous relation is defined as the presence of correlation between error term and dependent variable that relate causal link between variables described in model, inadequate quality of data, auto-regression and auto-correlation, related variables omission (Mileva 2007; Wooldridge 2013).

The Dynamic Panel model, developed by Arellano \& Bond, is recognized as Difference GMM estimator, as it uses the differences of lags as instrumental variables. Further, the Difference GMM have choice to do analysis through two options i.e., One step GMM and Two step GMM, depending on the homoscedasticity or hetrocedasticity of the weighting matrix. Academic Literature reveals that two step GMM method is more effective with use of hetrocedastic weighting matrix in the analysis (Labra and Torrecillas 2018). Another issue related with dynamic panel model is the presence of over-identification problem that can be effectively checked by Sargan \& Hansen tests. Also the number of cross-sections must be larger than the total of instruments used in order to evade the over-identification of model (Roodman 2009). As the present study have the number of cross-sections (banks) that are larger than number of instruments used, so the over-identification problem can be avoided. The study also employs the Arellano and Bond autocorrelation test in order to test the serial correlation in error terms.

The empirical design is proposed to analyze whether banks with diverse capitalization level respond in a different way against economic indicators, ownership structure, and bank specific characteristics. The observed models are specified by following equations that includes interaction terms which are product of excess capital with real GDP, monetary policy indicator, ownership structure, and bank specific characteristics; all the bank related and economic variables refer to $t-1$ in order to avoid an endogeniety bias $^{1}$ (Gambacorta and Mistrulli 2004; Kashyap and Stein 2000):

$$
\begin{aligned}
\Delta \operatorname{lnLoan}_{i t}= & \mu_{i}+\alpha \Delta \operatorname{lnLoan}_{i t-1}+\beta \Delta M P_{t}+\gamma I N F_{t}+\delta \Delta \ln G D P_{t}+\lambda E X C A P_{i t} \\
& +\rho E X C A P_{i t} \Delta M P_{t}+\tau E X C A P_{i t} \Delta \ln G D P_{t}+\Phi_{i t}+\varepsilon_{i t} \\
\Delta \operatorname{lnLoan}_{i t}= & \mu_{i}+\alpha \Delta \operatorname{lnLoan}_{i t-1}+\beta \Delta M P_{t}+\gamma I N F_{t}+\delta \Delta \ln G D P_{t}+\lambda E X C A P_{i t} \\
& +\omega O W N_{i t}+\rho E X C A P_{i t} \Delta M P_{t}+\tau E X C A P_{i t} \Delta \ln G D P_{t} \\
& +\theta E X C A P_{i t} O W N_{i t}+\Phi_{i t}+\varepsilon_{i t}
\end{aligned}
$$

where $i=1, \ldots \mathrm{N}$ (i.e., number of banks), $t=1, \ldots \mathrm{T}$ (Time period)

Loan $_{i t}=$ loans of bank $i$ in quarter $t$

$M P t=$ monetary policy indicator

$G D P_{t}=$ real GDP growth rate

$I N F_{t}=$ inflation rate

$E X C A P_{i t}=$ excess capital measure

OWNit = ownership type and ownership concentration

$\Phi_{i t}=$ control variables.

The excess capital is measured by taking the difference between regulatory capital and minimum capital requirements. The regulatory capital ratio is defined as Tier 1 capital ratio that is more appropriate measure of bank capital. The control variables set (i.e., $\Phi_{i t}$ ) includes a liquidity variable, specified by sum of cash and marketable securities to total assets ratio and size factor, specified by log of total assets. As like the other bank-specific variables, bank size and liquidity indicators also refer to

1 Because of the possibility of endogenous relation between dependent and independent variables, the current study employs lag values of all bank related and economic variables. As the large number of lags in model inflate the standard errors of coefficients and can increase an estimation bias, so we use one year lag value in model estimation (Hanck et al. 2019; Wooldridge 2013). 
$t-1$ to avoid the endogeniety bias. The interest rate is proxy of monetary policy indicator measured by central bank policy rate between banks and credit institutes or the rate on key bank refinancing operations. Consumer price index (CPI) as inflation and real GDP growth rate are employed to control for loan demand effect and to capture cyclical movement. The details of the variables, used in this study, is given in Table 1.

The robustness of the results is tested in numerous ways. The first robustness test includes the interaction term between excess capital and liquidity indicator. This term examines the impact of excess capital on bank lending through bank specific characteristics i.e., its liquidity.

$$
\begin{aligned}
\Delta \operatorname{lnLoan}_{i t}= & \mu_{i}+\alpha \Delta \operatorname{lnLoan}_{i t-1}+\beta \Delta M P_{t}+\gamma I N F_{t}+\delta \Delta \ln G D P_{t}+\lambda E X C A P_{i t} \\
& +\rho E X C A P_{i t} \Delta M P_{t}+\tau E X C A P_{i t} \Delta \ln G D P_{t}+\theta E X C A P_{i t} L I Q_{i t}+\Phi_{i t} \\
& +\varepsilon_{i t}
\end{aligned}
$$

The second robustness test includes the interaction term between excess capital and bank size. This term examines the impact of excess capital on bank lending through bank specific characteristics i.e., its size.

$$
\begin{aligned}
\Delta \operatorname{lnLoan}_{i t}= & \mu_{i}+\alpha \Delta \operatorname{lnLoan}_{i t-1}+\beta \Delta M P_{t}+\gamma I N F_{t}+\delta \Delta \ln G D P_{t}+\lambda E X C A P_{i t} \\
& +\rho E X C A P_{i t} \Delta M P_{t}+\tau E X C A P_{i t} \Delta \ln G D P_{t}+\theta E X C A P_{i t} \operatorname{SIZE}_{i t}+\Phi_{i t} \\
& +\varepsilon_{i t}
\end{aligned}
$$

The third robustness rest is to incorporate interaction term between monetary policy indicator and liquidity factor in basic regression model. The rationale for this analysis is to confirm whether asymmetric effect of monetary policy because of excess capital remain appropriate; the interaction term between liquidity and monetary policy indicator, in fact characterize an important factor. The equation is as follows:

$$
\begin{aligned}
\Delta \ln _{\text {Loan }_{i t}=} & \mu_{i}+\alpha \Delta \operatorname{lnLoan}_{i t-1}+\beta \Delta M P_{t}+\gamma I N F_{t}+\delta \Delta \ln G D P_{t}+\lambda E X C A P_{i t} \\
& +\rho E X C A P_{i t} \Delta M P_{t}+\tau E X C A P_{i t} \Delta \ln G D P_{t}+\theta L I Q_{i t} \Delta M P_{t}+\Phi_{i t}+\varepsilon_{i t}
\end{aligned}
$$

The next robustness test is to set up further interaction terms uniting excess capital with inflation, recreating the basic model (1). The motive behind the test is the likely existence of endogeniety between capital and inflation; excess capital can be high when inflation is higher or vice-versa.

$$
\begin{aligned}
\Delta \operatorname{lnLoan}_{i t}= & \mu_{i}+\alpha \Delta \operatorname{lnLoan}_{i t-1}+\beta \Delta M P_{t}+\gamma I N F_{t}+\delta \Delta \ln G D P_{t}+\lambda E X C A P_{i t} \\
& +\rho E X C A P_{i t} \Delta M P_{t}+\tau E X C A P_{i t} \Delta \ln G D P_{t}+\theta E X C A P_{i t} I N F_{t}+\Phi_{i t} \\
& +\varepsilon_{i t}
\end{aligned}
$$

As the purpose of the study is to investigate whether banks with diverse capitalization level respond in a different way to monetary policy, GDP indicator, ownership structure, and bank specific characteristics, so we divide the banks into two subsamples based on their excess capital. A bank is said to be well-capitalized if its excess capital ratio is greater than or equal to 90th percentile, and described as less-capitalized if the ratio is less than or equal to 10th percentile. The study also check the robustness of results by dividing sample into three subsample based on geographical position, i.e., South-East region, South Asian region, and East Asia region. The subsamples results are used to test the overall significance of results.

\section{Results and Discussion}

Table 2 reports the descriptive statistics of the combined sample and individual countries. The combined sample study results are given in Tables 3 and 4 that represent the long-term elasticity of bank lending with respect to independent variables. The models are estimated by using Arellano and Bond (1991) Two-step Dynamic Panel GMM technique that provides the consistency and efficiency. 
This methodology ensures that models are not subject to order two serial correlation and instruments employed are also valid. The presence of bank capital asymmetric effect is tested by considering the four samples including Combined Asian emerging markets, and also subsamples, East-Asia emerging economies, South-Asia emerging markets, and South-East Asia emerging economies, because of the changes in bank-specific, macroeconomic, and ownership characteristics that are discussed in previous literature.

Table 2. Descriptive Statistics.

\begin{tabular}{|c|c|c|c|c|c|c|c|c|c|}
\hline \multirow{2}{*}{ Variable } & \multicolumn{3}{|c|}{ Combined Sample } & \multicolumn{3}{|c|}{ China } & \multicolumn{3}{|c|}{ India } \\
\hline & Obs. & Mean & Std. Dev & Obs. & Mean & Std. Dev & Obs. & Mean & Std. Dev \\
\hline Excap & 2066 & 6.17 & 35.23 & 445 & 4.17 & 46.86 & 526 & 2.05 & 4.50 \\
\hline Loan Growth & 1911 & 17.69 & 29.31 & 410 & 18.74 & 10.35 & 488 & 10.53 & 13.81 \\
\hline SIZE & 2066 & 13.52 & 2.128 & 445 & 13.29 & 1.80 & 526 & 13.60 & 1.41 \\
\hline LIQ & 2066 & 6.95 & 7.05 & 445 & 6.18 & 4.68 & 526 & 3.79 & 3.28 \\
\hline MO & 830 & 1.64 & 4.15 & 205 & 1.53 & 4.32 & 232 & 1.44 & 4.39 \\
\hline FO & 1054 & 19 & 17.11 & 201 & 19.28 & 17.21 & 336 & 18.76 & 17.49 \\
\hline OC5 & 1212 & 60.93 & 22.10 & 202 & 63.31 & 18.61 & 297 & 57.47 & 21.39 \\
\hline OC10 & 1243 & 55.49 & 25.95 & 221 & 58.81 & 23.41 & 312 & 48.72 & 26.26 \\
\hline \multirow{2}{*}{ Variable } & \multicolumn{3}{|c|}{ Pakistan } & \multicolumn{3}{|c|}{ Indonesia } & \multicolumn{3}{|c|}{ Malaysia } \\
\hline & Obs. & Mean & Std. Dev & Obs. & Mean & Std. Dev & Obs. & Mean & Std. Dev \\
\hline Excap & 258 & 5.80 & 9.96 & 346 & 14.98 & 65.32 & 138 & 3.67 & 2.48 \\
\hline Loan Growth & 239 & 16.70 & 22.75 & 319 & 23.65 & 62.38 & 128 & 10.76 & 11.15 \\
\hline SIZE & 258 & 12.27 & 1.25 & 346 & 16.41 & 1.96 & 138 & 11.59 & 0.90 \\
\hline LIQ & 258 & 6.39 & 4.77 & 346 & 10.73 & 10.79 & 138 & 13.41 & 7.56 \\
\hline MO & 83 & 1.31 & 2.43 & 38 & 4.59 & 7.14 & 90 & 1.72 & 3.45 \\
\hline FO & 122 & 14.77 & 13.25 & 91 & 25.36 & 17.47 & 99 & 19.38 & 18.77 \\
\hline OC5 & 166 & 60.41 & 24.44 & 211 & 61.39 & 22.87 & 95 & 63.57 & 17.35 \\
\hline OC10 & 164 & 54.72 & 30.13 & 200 & 56.80 & 24.07 & 95 & 59.30 & 25.41 \\
\hline \multirow{2}{*}{ Variable } & \multicolumn{3}{|c|}{ Philippines } & \multicolumn{6}{|c|}{ Thailand } \\
\hline & Obs. & Mean & Std. Dev & \multicolumn{2}{|c|}{ Obs. } & \multicolumn{2}{|c|}{ Mean } & \multicolumn{2}{|c|}{ Std. Dev } \\
\hline Excap & 203 & 10.23 & 13.23 & \multicolumn{2}{|c|}{150} & \multicolumn{2}{|c|}{3.72} & \multicolumn{2}{|c|}{3.42} \\
\hline Loan Growth & 188 & 15.52 & 20.78 & \multicolumn{2}{|c|}{139} & \multicolumn{2}{|c|}{8.97} & \multicolumn{2}{|c|}{11.18} \\
\hline SIZE & 203 & 11.98 & 1.59 & \multicolumn{2}{|c|}{150} & \multicolumn{2}{|c|}{13.32} & \multicolumn{2}{|c|}{1.13} \\
\hline LIQ & 203 & 10.60 & 7.05 & \multicolumn{2}{|c|}{150} & \multicolumn{2}{|c|}{1.60} & \multicolumn{2}{|c|}{0.90} \\
\hline MO & 108 & .80 & 1.34 & \multicolumn{2}{|c|}{64} & \multicolumn{2}{|c|}{2.08} & \multicolumn{2}{|c|}{4.52} \\
\hline FO & 97 & 20.92 & 17.90 & & & 17 & & & 5.61 \\
\hline OC5 & 133 & 52.82 & 23.64 & & & 74 & & & .15 \\
\hline OC10 & 143 & 50.06 & 23.73 & & & 71 & & & 1.54 \\
\hline
\end{tabular}

Descriptive statistics reports the summary statistics of main variables included in combined sample and also in individual countries. 
Table 3. Combined Sample Results.

\begin{tabular}{|c|c|c|c|c|c|c|c|c|c|c|}
\hline \multirow{2}{*}{ Annual Lending Growth Rate } & \multicolumn{2}{|c|}{ Model 1} & \multicolumn{2}{|c|}{ Model 3} & \multicolumn{2}{|c|}{ Model 4} & \multicolumn{2}{|c|}{ Model 5} & \multicolumn{2}{|c|}{ Model 6} \\
\hline & Coeff. & $p$-Value & Coeff. & $p$-Value & Coeff. & $p$-Value & Coeff. & $p$-Value & Coeff. & $p$-Value \\
\hline Cons. & $144.6^{* * * *}$ & 0.000 & $158.6^{* * *}$ & 0.000 & $141.5^{* * *}$ & 0.000 & $143.5^{* * *}$ & 0.000 & $142.9^{* * *}$ & 0.000 \\
\hline Loan $(t-1)$ & 0.020 & 0.783 & $-0.122 * * *$ & 0.000 & 0.016 & 0.826 & 0.019 & 0.796 & 0.073 & 0.447 \\
\hline MP & $-1.334 * * *$ & 0.003 & $-0.902 * *$ & 0.019 & $-1.301 * * *$ & 0.005 & 0.316 & 0.742 & $-1.489 * * *$ & 0.001 \\
\hline GDP & -0.022 & 0.947 & 0.320 & 0.359 & 0.206 & 0.511 & 0.190 & 0.626 & 0.043 & 0.887 \\
\hline Excap & 0.216 & 0.522 & -0.206 & 0.600 & -0.204 & 0.776 & 0.316 & 0.397 & 0.278 & 0.297 \\
\hline $\begin{array}{c}\text { Excap*GDP } \\
\text { (risk-aversion effect) }\end{array}$ & 0.005 & 0.934 & 0.051 & 0.337 & 0.017 & 0.735 & -0.013 & 0.849 & 0.022 & 0.635 \\
\hline $\begin{array}{c}\text { Excap*GDP } \\
\text { (less-capitalize banks) }\end{array}$ & 0.012 & 0.901 & & & & & 0.006 & 0.948 & & \\
\hline $\begin{array}{c}\text { Excap*GDP } \\
\text { (well-capitalize banks) }\end{array}$ & $0.520^{* * *}$ & 0.000 & & & & & $0.531 * * *$ & 0.000 & & \\
\hline $\begin{array}{c}\text { Excap*MP } \\
\text { (bank-lending channel) }\end{array}$ & -0.002 & 0.967 & -0.021 & 0.534 & 0.014 & 0.712 & 0.041 & 0.380 & 0.020 & 0.631 \\
\hline $\begin{array}{c}\text { Excap*MP } \\
\text { (less-capitalize banks) }\end{array}$ & -1.316 & 0.118 & -0.935 & 0.182 & -1.393 & 0.126 & -1.322 & 0.110 & -1.408 & 0.158 \\
\hline $\begin{array}{c}\text { Excap*MP } \\
\text { (well-capitalize banks) }\end{array}$ & 2.054 ** & 0.008 & 0.300 ** & 0.051 & $1.917^{* * *}$ & 0.004 & 2.132 ** & 0.008 & 1.780 ** & 0.008 \\
\hline Excap*LIQ & & & 0.002 & 0.133 & & & & & & \\
\hline Excap*LIQ (less-capitalize banks) & & & 0.074 & 0.209 & & & & & & \\
\hline Excap*LIQ (well-capitalize banks) & & & $0.200^{* * * *}$ & 0.000 & & & & & & \\
\hline Excap*SIZE & & & & & 0.032 & 0.673 & & & & \\
\hline Excap*SIZE (less-capitalize banks) & & & & & 0.034 & 0.566 & & & & \\
\hline Excap*SIZE (well-capitalize banks) & & & & & $0.233^{* * *}$ & 0.000 & & & & \\
\hline LIQ*MP & & & & & & & $-0.379^{*}$ & 0.055 & & \\
\hline Excap*INF & & & & & & & & & -0.033 & 0.326 \\
\hline Excap*INF (less-capitalize banks) & & & & & & & & & 0.028 & 0.714 \\
\hline Excap*INF (well-capitalize banks) & & & & & & & & & $0.350 *$ & 0.063 \\
\hline LIQ & $0.876^{* * *}$ & 0.003 & 0.493 ** & 0.050 & $0.875^{* * *}$ & 0.002 & $0.807^{* * *}$ & 0.004 & $0.864^{* * *}$ & 0.002 \\
\hline SIZE & $-10.06 * * *$ & 0.000 & $-10.84^{* * *}$ & 0.000 & $-9.938^{* * *}$ & 0.000 & $-10.09 * * *$ & 0.000 & $-9.958^{* * *}$ & 0.000 \\
\hline AR(1), AR(2), (p-value) & 0.006 & 0.610 & 0.016 & 0.197 & 0.005 & 0.655 & 0.006 & 0.721 & 0.009 & 0.494 \\
\hline Wald chi2 (Prob) & 0.0000 & & 0.0000 & & 0.0000 & & 0.0000 & & 0.0000 & \\
\hline No. of banks & 155 & & 155 & & 155 & & 155 & & 155 & \\
\hline No. of Obs. & 1601 & & 1601 & & 1601 & & 1601 & & 1601 & \\
\hline
\end{tabular}

Table 3 reports the combined sample (Asian emerging markets) results. The current study employs the Arellano and Bond (1991) Two-step Dynamic Panel GMM technique to estimate the model and results report the hetro-robust standard errors in order to account for possible heterogeneity. The dependent variable is the annual growth rate of bank loans. The estat abond test is used to check for the possibility of error terms autocorrelation. ${ }^{* * *}, * * * *$ represents significance level at $1 \%, 5 \%$ and $10 \%$ respectively. We also estimate model by including country fixed effects and time fixed effects in model (time fixed and country fixed effects are not reported here), but there is no change in the significance of model. The panel unit-root test are reported in Table A5. 
Table 4. Ownership Model Results.

\begin{tabular}{|c|c|c|c|c|c|c|c|c|}
\hline \multirow[t]{2}{*}{ Annual Lending Growth Rate } & \multicolumn{2}{|c|}{$\begin{array}{c}\text { Model } 2 \\
\text { (OC5) }\end{array}$} & \multicolumn{2}{|c|}{$\begin{array}{l}\text { Model } 2 \\
\text { (OC10) }\end{array}$} & \multicolumn{2}{|c|}{$\begin{array}{l}\text { Model } 2 \\
\text { (MO) }\end{array}$} & \multicolumn{2}{|c|}{$\begin{array}{c}\text { Model } 2 \\
\text { (FO) }\end{array}$} \\
\hline & Coeff. & $p$-Value & Coeff. & $p$-Value & Coeff. & $p$-Value & Coeff. & $p$-Value \\
\hline Cons. & $102.8^{* *}$ & 0.011 & $133^{* * *}$ & 0.000 & $145.5^{* * *}$ & 0.000 & $190.3^{* * *}$ & 0.000 \\
\hline $\operatorname{Loan}(t-1)$ & 0.067 & 0.559 & -0.073 & 0.277 & $-0.098 * * *$ & 0.000 & $-0.214^{* * *}$ & 0.000 \\
\hline MP & -1.555 ** & 0.042 & $-0.805^{*}$ & 0.072 & -1.127 & 0.120 & $-1.049 *$ & 0.066 \\
\hline GDP & 0.559 & 0.195 & 0.415 & $0.100^{*}$ & $0.746^{* *}$ & 0.014 & 0.295 & 0.290 \\
\hline Excap & -0.042 & 0.955 & -0.721 & 0.229 & 1.365 ** & 0.017 & $1.354^{* *}$ & 0.031 \\
\hline $\begin{array}{c}\text { Excap*GDP } \\
\text { (risk-aversion effect) }\end{array}$ & -0.017 & 0.866 & 0.011 & 0.835 & $0.059^{* *}$ & 0.021 & 0.026 & 0.503 \\
\hline $\begin{array}{c}\text { Excap*MP } \\
\text { (bank-lending channel) }\end{array}$ & 0.169 & 0.533 & -0.090 & 0.243 & 0.011 & 0.927 & 0.047 & 0.377 \\
\hline Oc5 & $-0.112 *$ & 0.075 & & & & & & \\
\hline Excap* ${ }^{*} \mathrm{OC} 5$ & $0.022 * *$ & 0.010 & & & & & & \\
\hline $\begin{array}{c}\text { Excap* }{ }^{*} \mathrm{OC} 5 \\
\text { (less-capitalize banks) }\end{array}$ & 0.008 & 0.481 & & & & & & \\
\hline Excap ${ }^{*} \mathrm{OC5}$ (well-capitalize banks) & 0.006 & 0.483 & & & & & & \\
\hline OC10 & & & -0.105 & 0.118 & & & & \\
\hline Excap*OC10 & & & $0.029^{* * *}$ & 0.001 & & & & \\
\hline $\begin{array}{c}\text { Excap*OC10 } \\
\text { (less-capitalize banks) }\end{array}$ & & & 0.011 & 0.520 & & & & \\
\hline Excap* OC10 (well-capitalize banks) & & & 0.002 & 0.301 & & & & \\
\hline MO & & & & & -0.417 & 0.562 & & \\
\hline Excap*MO & & & & & 0.042 & 0.554 & & \\
\hline Excap*MO (less-capitalize banks) & & & & & -0.037 & 0.792 & & \\
\hline Excap*MO (well-capitalize banks) & & & & & $-0.232 *$ & 0.070 & & \\
\hline FO & & & & & & & $0.178^{*}$ & 0.090 \\
\hline Excap* ${ }^{*} \mathrm{O}$ & & & & & & & -0.022 & 0.175 \\
\hline Excap*FO (less-capitalize banks) & & & & & & & 0.002 & 0.804 \\
\hline Excap*FO (well-capitalize banks) & & & & & & & -0.006 & 0.779 \\
\hline LIQ & $0.807^{* * *}$ & 0.035 & 0.401 ** & $0.047^{* * * *}$ & 0.001 & 0.998 & -0.000 & 1.000 \\
\hline SIZE & $-7.105 * *$ & 0.009 & $-8.890 * * *$ & 0.000 & $-10.48^{* * * *}$ & 0.000 & $-13.59 * * *$ & 0.000 \\
\hline $\operatorname{AR}(1), \operatorname{AR}(2),(p$-value $)$ & 0.052 & 0.516 & 0.039 & 0.354 & 0.082 & 0.110 & 0.101 & 0.138 \\
\hline Wald chi2 (Prob) & 0.0000 & & 0.0000 & & 0.0000 & & 0.0000 & \\
\hline No. of banks & 124 & & 128 & & 88 & & 112 & \\
\hline No. of Obs. & 954 & & 976 & & 651 & & 828 & \\
\hline
\end{tabular}

Table 4 reports the combined sample (Asian emerging markets) model 2 results. The current study employs the Arellano and Bond (1991) Two-step Dynamic Panel GMM technique to estimate the model and results report the hetro-robust standard errors in order to account for possible heterogeneity. The dependent variable is the annual growth rate of bank loans. The estat abond test is used to check for the possibility of error terms autocorrelation. The ownership structure includes the ownership type (MO and FO) and ownership concentration (OC5 and OC10). ${ }^{* * *}, * * * *$ represents significance level at $1 \%, 5 \%$, and $10 \%$ respectively. 
The effect of excess capital on bank lending can be analyzed in Tables 3 and 4, which shows the positive relation between bank excess capital and lending but the effect is significant only in two cases. The result proves that bank with excess capital are less effected by capital constraints and enjoy opportunities to extend their credit portfolios. The monetary policy indicator has the expected negative and significant impact on bank lending in all cases. Estimating the monetary policy effect between banks with diverse capital ratios is equivalent to examining the significance of long-term coefficients of the interaction term between the monetary policy indicator and bank excess capital. The results show that in case of low-capitalized banks, the interaction between the excess capital and monetary policy shock is negative but the result proves not to be significant in any case. The bank lending channel theory predicts that banks with high capital ratios are not much effected by tight monetary policy as they have an ability to raise uninsured form of funding. As bank equity affects the ability of banks to issue uninsured form of debt and consequently restrain the effect of deposit fall on lending through the following mechanism. Reserveable deposits drop subsequent to a monetary contraction and banks issue nonreservable loan in order to shield their portfolios of loan. Because this nonreservable financing is usually uninsured (i.e., CDs or bonds), banks suffer the problem of adverse selection; less-capitalized banks are recognized by market riskier, so have more problems to issue bonds and therefore have low capacity to protect their credit relationship. But in case of well-capitalized banks the interaction between the excess capital and monetary policy shock have positive sign and the result proves to be significant in all cases, which means that banks with excess capital have ability to raise uninsured form of financing and shield their loan portfolios in case of monetary tightening as compared to less capitalize banks that reduce their lending (Gambacorta and Mistrulli 2004; Heuvel 2002; Kishan and Opiela 2000; Xiong 2013). So, we conclude that bank lending channel is proved to be weak in case of well-capitalized banks, that can issue nonreservable liabilities and shield their loan portfolios, but less-capitalized banks have the presence of bank lending channel but the result is not proved to be significant in this case.

The results also imply a positive relation between bank excess capital and output indicator (i.e., GDP), which means that an increase in GDP is likely to increase the lending and the result is proved to be significant. The interaction term between the excess capital and output is also positive and proves to be significant in most of cases, which means that the credit supply of banks with excess capital is dependent on business cycles (See Table 3). The positive relation shows that banks with excess capital are likely to increase their lending in case of economic growth. Bank capital manipulate the response of lending to GDP (i.e., output) and the effect depends on relationship between the bank capital and its risk-aversion behavior. The results show a positive and significant relation between bank lending and output indicator in case of well-capitalized banks. Which means that well-capitalized banks are less risk-averse and react more to business cycle fluctuations because they have a portfolio of borrowers, ex ante, who are more risky and retain excess capital because their lending is risky (Gambacorta and Mistrulli 2004).

In case of bank ownership structure, the study includes ownership type i.e., managerial ownership (MO) and Foreign ownership (FO), and ownership concentration (OC) i.e., percentage of shares held by top three shareholders who hold greater than or equal to $10 \%$ of shares (OC10), or percentage of shares held by top five shareholders who hold greater than or equal to $5 \%$ of shares (OC5). The study results show that ownership concentration have negative relation with bank lending activity but the results are not proved to be significant in both cases. The interaction terms between the ownership concentration and excess capital have positive and significant relation with bank lending, which means that banks with excess capital ratios and ownership concentration lead towards an increase in lending activity. Managerial ownership has a negative and insignificant relation with lending activity but the interaction term between $\mathrm{MO}$ and excess capital has significant negative relation with bank lending in case of well-capitalized banks. The finding implies that well-capitalized banks with managerial ownership tend to reduce lending which validates the agency theory of corporate governance that management act for their own interests as compared to other stakeholders and owners' interests. 
The foreign ownership has a significant positive relation with bank lending growth rates that means banks with foreign ownership lead towards an increase in lending activity. The interaction between the excess capital and foreign ownership is not proved to be significant.

However, numerous latest studies showed that foreign ownership banks reduce the credit supply during the financial crisis of 2008 in CEE (Central Eastern and European) region (Cull and Peria 2013). The current study results do not validate these findings, as our sample encompasses the Asian emerging economies. Most of them are not directly affected by the recent global financial crisis of 2008 . But we validate the findings of studies which report that foreign banks entry bring more efficiency in banking industry (Bonin et al. 2005; Clarke et al. 2006; Fries and Taci 2005).

The bank specific control variables include the liquidity and bank size. Liquidity has a significant positive and size has a significant negative relation with bank lending in all cases. Bank liquidity and size are also interacted with excess capital to examine the indirect effect on bank lending. The interaction between excess capital and liquidity has positive relation with bank lending that validates the 'risk-absorption hypothesis', because equity improves banks risk-bearing capability, but the effect is proved to be significant in case of well-capitalized banks. The hypothesis that 'The impact of bank equity on credit supply is directly related with liquidity level of bank' points to the fact that bank capital impact on lending shows a rising slope depending on liquidity level; in another way, we anticipate that banks with high level of liquid asset are likely to provide more credit than the banks with low level of liquid asset. Until acquiring enough liquid assets, bank with low level of liquid assets are expected to invest further funds in liquid assets rather than providing loans as equity increase. This forecast is consistent with the previous arguments that low liquidity banks are expected to decrease loans to sustain their holdings of liquid assets above a severely low position (Berrospide and Edge 2010; Cornett et al. 2011; Kashyap and Stein 2000).

The interaction between excess capital and size has the positive relation with bank lending, but the effect is proven to be significant only in case of well-capitalized banks. The interaction of liquidity factor with monitory policy indicator has negative and significant relation with bank lending, implying that the effect of tight monetary policy is larger for banks with more liquidity and easier access to uninsured forms of financing. The final robustness test includes the interaction term between excess capital and inflation and results show a positive impact on bank lending, but the result is proved to be significant only in case of well-capitalized banks. However, the base model results significance remain unchanged in case of all estimations which validate the robustness of results. The study also checks the robustness of results by dividing the sample into three subsamples based on geographical positions. The subsamples results are given in Tables A1-A3 in Appendix A and they prove the significance of the overall sample results.

\section{Conclusions}

The current study examines the relation between regulatory capital requirements, ownership structure, and bank lending in the case of Asian emerging markets over a period of 2004-2017. The study employs Arellano and Bond (1991) Two-step Dynamic Panel GMM estimation technique that provides the consistency and efficiency. The methodology ensures that models are not subject to order two serial correlation and instruments employed are also valid. The presence of bank capital asymmetric effects is tested by dividing the Asian emerging markets sample into three subsamples, which includes East-Asia emerging economies, South-Asia emerging markets, and South-East Asia emerging economies.

The results of the study show that the effect of excess capital on bank lending is positive and proves to be significant. The positive relation implies that banks with excess capital are less effected by capital constraints and enjoy opportunities to extend their credit portfolios. The monetary policy indicator has the expected negative and significant impact on bank lending in all cases. The results show that in case of low-capitalized banks the interaction, between the excess capital and monetary policy indicator, is negative but the result is not proved to be significant. However, in the case of 
well-capitalized banks, the interaction between the excess capital and monetary policy indicator has positive sign and proves to be significant, which means that banks with excess capital have ability to raise uninsured form of financing and shield their loan portfolios in case of monetary tightening as compared to less-capitalized banks that reduce their lending (Gambacorta and Mistrulli 2004; Heuvel 2002; Kishan and Opiela 2000; Xiong 2013).

The results also imply a positive relation between bank excess capital and output indicator (i.e., GDP), which means that an increase in GDP is likely to increase the lending and the result is also proves to be significant. The interaction term between the excess capital and output is also positive and proves to be significant, which means that the credit supply of banks with excess capital is dependent on business cycles.

In case of bank ownership structure, the study includes ownership type and ownership concentration. The findings of the bank ownership model show that ownership concentration has negative relation with bank lending activity but the results are not proved to be significant in both cases. The interaction terms between the ownership concentration and excess capital have positive and significant relation with bank lending, which means that banks with excess capital ratios and ownership concentration lead towards an increase in lending activity. Managerial ownership has a negative and insignificant relation with lending activity but the interaction term between managerial ownership and excess capital has significant negative relation with bank lending in case of well-capitalized banks. The finding implies that well-capitalized banks with managerial ownership tend to reduce lending which validate the agency theory of corporate governance, which means that management act for their own interests as compared to other stakeholders' interests. The foreign ownership has a significant positive relation with bank lending that means banks with foreign ownership lead towards an increase in lending activity. The interaction between the excess capital and foreign ownership is not proved to be significant. However, numerous latest studies show that foreign-owned banks reduce credit supply during the financial crisis of 2008 in CEE region (Cull and Peria 2013). The current study results do not validate these findings as our sample encompasses the Asian emerging economies most of them are not directly affected by the recent global financial crisis of 2008. The study also checks the robustness of results by dividing sample into three subsample based on geographical positions. The subsamples results prove the significance of overall sample results.

The study proposes various policy implications. First, the effect of excess capital on bank lending is positive which implies that banks with excess capital are less effected by capital constraints and enjoy opportunities to extend their credit portfolios. As the present study is conducted in Asian emerging economies, most of which are not directly affected by the financial crisis of 2007, the results imply that Basel regulatory reforms should take into account the regional consideration as the banks in Asian economies have already high capital ratios. And the further increase in capital requirements may increase their cost and hamper the role of banks as liquidity providers. Second, well-capitalized banks behave differently from less-capitalized banks in response to economic indicators and also under different ownership patterns, so there is a need to account these changes when implementing policy actions.

Author Contributions: Conceptualization, Y.A.; Data curation, Y.A.; Formal analysis, Y.A.; Methodology, Y.A.; Supervision, G.M.K.; Writing—original draft, Y.A.; Writing-review \& editing, G.M.K.; Resources and Software, T.Y.

Funding: This research received no external funding.

Conflicts of Interest: The authors declare no conflict of interest. 


\section{Appendix A}

Table A1. South-East region Results.

\begin{tabular}{|c|c|c|c|c|c|c|c|c|c|c|}
\hline \multirow{2}{*}{ Annual Lending Growth Rate } & \multicolumn{2}{|c|}{ Model 1} & \multicolumn{2}{|c|}{ Model 3} & \multicolumn{2}{|c|}{ Model 4} & \multicolumn{2}{|c|}{ Model 5} & \multicolumn{2}{|c|}{ Model 6} \\
\hline & Coeff. & $p$-Value & Coeff. & $p$-Value & Coeff. & $p$-Value & Coeff. & $p$-Value & Coeff. & $p$-Value \\
\hline Cons. & $306.1^{* * *}$ & 0.001 & $324.9 * * *$ & 0.000 & $303.98^{* * *}$ & 0.001 & $305.24^{* * *}$ & 0.001 & $328.2^{* * *}$ & 0.000 \\
\hline $\operatorname{Loan}(t-1)$ & -0.052 & 0.382 & -0.052 & 0.373 & -0.052 & 0.378 & -0.048 & 0.425 & -0.051 & 0.376 \\
\hline MP & -2.896 & $0.030^{* *}$ & -2.910 & $0.030^{* *}$ & -2.839 & $0.028^{* *}$ & 0.068 & 0.980 & -3.334 & $0.007^{* *}$ \\
\hline GDP & 0.306 & 0.554 & 0.358 & 0.510 & 0.366 & 0.501 & 0.457 & 0.414 & 0.386 & 0.431 \\
\hline INF & & & & & & & & & -0.490 & 0.344 \\
\hline Excap & -0.369 & 0.416 & -0.507 & 0.428 & -0.676 & 0.328 & -0.276 & 0.537 & -0.438 & 0.408 \\
\hline Excap*GDP (risk-aversion effect) & 0.068 & 0.365 & 0.071 & 0.417 & 0.048 & 0.591 & 0.054 & 0.474 & 0.061 & 0.415 \\
\hline Excap*GDP (less-capitalize banks) & -0.206 & 0.227 & -0.206 & 0.219 & -0.171 & 0.315 & -0.185 & 0.286 & -0.199 & 0.221 \\
\hline Excap*GDP (well-capitalize banks) & $0.597^{* * *}$ & 0.000 & $0.60^{* * *}$ & 0.000 & $0.599 * * *$ & 0.000 & $0.615^{* * *}$ & 0.000 & $0.602 * * *$ & 0.000 \\
\hline Excap*MP (bank-lending channel) & 0.050 & 0.432 & 0.049 & 0.442 & 0.043 & 0.496 & 0.104 & 0.201 & 0.072 & 0.380 \\
\hline Excap*MP (less-capitalize banks) & -3.202 & 0.233 & -3.167 & 0.217 & -2.869 & 0.271 & -2.955 & 0.279 & -3.067 & 0.233 \\
\hline Excap*MP (well-capitalize banks) & $2.592 * * *$ & 0.000 & $2.585^{* * *}$ & 0.000 & $2.604^{* * *}$ & 0.000 & $2.681^{* * *}$ & 0.000 & $2.629 * * *$ & 0.000 \\
\hline Excap*LIQ & & & 0.001 & 0.409 & & & & & & \\
\hline Excap*SIZE & & & & & 0.037 & 0.689 & & & & \\
\hline LIQ*MP & & & & & & & -0.449 & 0.149 & & \\
\hline Excap*INF & & & & & & & & & 0.010 & 0.299 \\
\hline LIQ & $1.746^{* * *}$ & 0.005 & $1.695 * * *$ & 0.004 & $1.757 * * *$ & 0.002 & $1.562 * * *$ & 0.003 & $1.690 * * *$ & 0.005 \\
\hline SIZE & $-22.16^{* * *}$ & 0.000 & $-23.38^{* * *}$ & 0.000 & $-22.07^{* * *}$ & 0.000 & $-22.02 * * *$ & 0.001 & $-23.62 * * *$ & 0.000 \\
\hline Wald chi2 (Prob) & 0.0000 & & 0.0000 & & 0.0000 & & 0.0000 & & 0.0000 & \\
\hline No. of banks & 63 & & 63 & & 63 & & 63 & & 63 & \\
\hline No. of Obs. & 648 & & 648 & & 648 & & 648 & & 648 & \\
\hline
\end{tabular}

Table A1 reports the South-East region results. The study employs the Arellano and Bond (1991) Two-step Dynamic Panel GMM technique to estimate the model and results report the hetero-robust standard errors in order to account for possible heterogeneity. The dependent variable is the annual growth rate of bank loans. The estat abond test is used to check for the possibility of error terms autocorrelation. South-East region include the Malaysia, Indonesia, Philippines and Thailand; South-Asia includes Pakistan and India; and East-Asia includes China. ${ }^{* * *},{ }^{* *},{ }^{*}$ represents significance level at $1 \%, 5 \%$ and $10 \%$ respectively. 
Table A2. Ownership Model Sub-Sample Results.

\begin{tabular}{|c|c|c|c|c|c|c|c|c|}
\hline \multirow{2}{*}{ Annual Lending Growth Rate } & \multicolumn{2}{|c|}{ South-East Region } & \multicolumn{2}{|c|}{ South-Asia Region } & \multicolumn{2}{|c|}{ South-Asia Region } & \multicolumn{2}{|c|}{ South-Asia Region } \\
\hline & Coeff. & $p$-Value & Coeff. & $p$-Value & Coeff. & $p$-Value & Coeff. & $p$-Value \\
\hline Cons. & $336.1 * * *$ & 0.000 & $226.04^{* * *}$ & 0.000 & $186.61^{* *}$ & 0.009 & $210.06^{* * *}$ & 0.000 \\
\hline $\operatorname{Loan}(t-1)$ & $-0.164 * * *$ & 0.000 & -0.163 * & 0.096 & $-0.174 *$ & 0.092 & -0.183 ** & 0.024 \\
\hline MP & -9.64 & 0.190 & -0.346 & 0.541 & -0.342 & 0.347 & -0.353 & 0.259 \\
\hline GDP & $1.556 *$ & 0.058 & $0.749 *$ & 0.072 & 0.352 & 0.233 & 0.322 & 0.259 \\
\hline INF & -0.289 & 0.723 & & & -0.108 & 0.746 & & \\
\hline Excap & $1.555 *$ & 0.056 & 0.284 & 0.646 & -0.435 & 0.283 & -0.677 & 0.191 \\
\hline Excap*GDP & $0.065 *$ & 0.080 & & & & & & \\
\hline Excap*MP & 0.115 & 0.432 & & & & & & \\
\hline LIQ & -0.541 & 0.312 & -0.752 & 0.200 & 0.257 & 0.569 & 0.207 & 0.653 \\
\hline SIZE & $-26.84 * * *$ & 0.000 & $-15.55^{* * *}$ & 0.000 & $-12.43^{* *}$ & 0.012 & $-14.01 * * *$ & 0.001 \\
\hline MO & 1.066 & 0.386 & 0.408 & 0.236 & & & & \\
\hline Excap*MO & -0.169 & 0.124 & & & & & & \\
\hline Excap ${ }^{*}$ MO (less-capitalize banks) & $-18.01 * * *$ & 0.000 & $0.249 *$ & 0.078 & & & & \\
\hline Excap*MO (well-capitalize banks) & 0.087 & 0.508 & -0.023 & 0.565 & & & & \\
\hline OC10 & & & & & -0.088 & 0.293 & & \\
\hline Excap ${ }^{*} \mathrm{OC} 10$ & & & & & $0.017^{* * *}$ & 0.001 & & \\
\hline OC5 & & & & & & & $-0.105 *$ & 0.0680 \\
\hline Excap*OC5 & & & & & & & $0.018^{* * *}$ & 0.001 \\
\hline Wald chi2 (Prob) & 0.0000 & & 0.0000 & & 0.0000 & & 0.0000 & \\
\hline No. of banks & 31 & & 32 & & 46 & & 43 & \\
\hline No. of Obs. & 237 & & 232 & & 352 & & 345 & \\
\hline
\end{tabular}

Table A2 reports the Subsamples model 2 results. The current study employs the Arellano and Bond (1991) Two-step Dynamic Panel GMM technique to estimate the model and results report the hetro-robust standard errors in order to account for possible heterogeneity. The dependent variable is the annual growth rate of bank loans. The estat abond test is used to check for the possibility of error terms autocorrelation. South-East region include the Malaysia, Indonesia, Philippines and Thailand; South-Asia includes Pakistan and India; and East-Asia includes China. ${ }^{* * *},{ }^{* *},{ }^{*}$ represents significance level at $1 \%, 5 \%$ and $10 \%$ respectively. 
Table A3. Main Model Results.

\begin{tabular}{|c|c|c|c|c|c|c|}
\hline \multirow{2}{*}{ Annual Lending Growth Rate } & \multicolumn{2}{|c|}{ South-Asia Region } & \multicolumn{2}{|c|}{ East-Asia Region } & \multicolumn{2}{|c|}{ East-Asia Region } \\
\hline & Coeff. & $p$-Value & Coeff. & $p$-Value & Coeff. & $p$-Value \\
\hline Cons. & 0.662 & 0.981 & $79.94 * *$ & 0.0190 & $91.41^{* *}$ & 0.017 \\
\hline $\operatorname{Loan}(t-1)$ & $0.261^{* *}$ & 0.008 & 0.021 & 0.838 & 0.022 & 0.832 \\
\hline MP & $-1.886^{* * *}$ & 0.000 & $-2.142^{* *}$ & 0.009 & $-2.062 * *$ & 0.011 \\
\hline GDP & $1.031^{* * *}$ & 0.002 & -0.257 & 0.703 & -0.392 & 0.584 \\
\hline INF & $0.599 *$ & 0.067 & $0.643^{* * *}$ & 0.003 & $0.655^{* * *}$ & 0.002 \\
\hline Excap & $0.927 * *$ & 0.013 & -1.592 & 0.216 & -4.435 & 0.172 \\
\hline Excap*GDP & 0.073 & 0.721 & 0.147 & 0.135 & $0.192 *$ & 0.088 \\
\hline Excap*MP & -0.080 & 0.558 & -0.145 & 0.433 & -0.196 & 0.265 \\
\hline Excap*LIQ & -0.069 & 0.115 & 0.063 & 0.245 & 0.065 & 0.230 \\
\hline Excap ${ }^{*}$ SIZE & & & & & 0.198 & 0.318 \\
\hline LIQ & -0.259 & 0.601 & -0.162 & 0.444 & -0.178 & 0.408 \\
\hline SIZE & -0.048 & 0.981 & $-4.622 * *$ & 0.026 & $-5.396^{* *}$ & 0.023 \\
\hline Wald chi2 (Prob) & 0.0000 & & 0.0000 & & 0.0000 & \\
\hline No. of banks & 57 & & 35 & & 35 & \\
\hline No. of Obs. & 613 & & 340 & & 340 & \\
\hline
\end{tabular}

Table A3 reports the Subsamples robustness results. The current study employs the Arellano and Bond (1991) Two-step Dynamic Panel GMM technique to estimate the model and the results report the hetro-robust standard errors in order to account for possible heterogeneity. The dependent variable is the annual growth rate of bank loans. The estat abond test is used to check for the possibility of error terms autocorrelation. South-East region include the Malaysia, Indonesia, Philippines and Thailand; South-Asia includes Pakistan and India; and East-Asia includes China. ${ }^{* * *}, * *, *$ represents significance level at $1 \%, 5 \%$ and $10 \%$ respectively. 
Table A4. Correlation Matrix.

\begin{tabular}{|c|c|c|c|c|c|c|c|c|c|c|c|c|c|}
\hline Variable & Excap & LIQ & SIZE & GDP & INF & Loan & MP & LIQ*MP & Excap*GDP & Excap*MP & Excap*LIQ & Excap*SIZE & Excap*INF \\
\hline Excap & 1 & & & & & & & & & & & & \\
\hline LIQ & 0.40 & 1 & & & & & & & & & & & \\
\hline SIZE & -0.07 & -0.08 & 1 & & & & & & & & & & \\
\hline GDP & -0.02 & -0.06 & -0.05 & 1 & & & & & & & & & \\
\hline INF & 0.00 & -0.09 & 0.03 & -0.17 & 1 & & & & & & & & \\
\hline Loan & 0.19 & 0.14 & -0.05 & 0.09 & 0.04 & 1 & & & & & & & \\
\hline MP & -0.01 & 0.03 & -0.07 & -0.08 & 0.17 & -0.02 & 1 & & & & & & \\
\hline LIQ*MP & -0.01 & -0.00 & -0.08 & -0.04 & 0.17 & -0.04 & 0.10 & 1 & & & & & \\
\hline Excap*GDP & 0.29 & 0.20 & -0.06 & 0.03 & -0.00 & 0.11 & -0.04 & -0.11 & 1 & & & & \\
\hline Excap*MP & 0.01 & 0.06 & -0.01 & -0.01 & 0.04 & 0.01 & 0.21 & 0.51 & -0.15 & 1 & & & \\
\hline Excap*LIQ & 0.54 & 0.40 & -0.04 & -0.01 & -0.00 & 0.16 & 0.00 & 0.02 & 0.56 & 0.10 & 1 & & \\
\hline Excap*SIZE & 0.49 & 0.35 & -0.02 & -0.03 & -0.001 & 0.19 & -0.03 & -0.06 & 0.89 & -0.05 & 0.81 & 1 & \\
\hline Excap*INF & 0.55 & 0.38 & -0.05 & -0.06 & 0.05 & 0.15 & 0.00 & -0.04 & 0.60 & -0.01 & 0.87 & 0.84 & 1 \\
\hline
\end{tabular}

Table A4 presents the correlation coefficients between all the variables used in the study. The dependent variable is annual growth rate of natural log of loans (Loan). The other variables represent the excess capital, bank-specific variables, macroeconomic variables and the interaction terms between the excess capital (Excap) and other variables.

Table A5. Panel Unit-root Test: Fisher-type unit-root test*.

\begin{tabular}{cccccc}
\hline & Phillips-Perron Test & \multicolumn{3}{c}{ Augmented Dickey-Fuller Test } \\
\hline Variable & Statistics & $p$-Value & Variable & Statistics & $p$-Value \\
\hline Loan & 1209.25 & 0.0000 & Loan & 1209.25 & 0.0000 \\
Excap & 864.31 & 0.0000 & Excap & 864.31 & 0.0000 \\
LIQ & 862.70 & 0.0000 & LIQ & 862.70 & 0.0000 \\
SIZE & 356.66 & 0.035 & SIZE & 356.66 & 0.035 \\
GDP & 1088.87 & 0.0000 & GDP & 1088.87 & 0.0000 \\
MP & 923.71 & 0.0000 & MP & 923.71 & 0.0000 \\
INF & 1214.28 & 0.0000 & INFC & 1214.28 & 0.0000 \\
MO & 398.19 & 0.0000 & MO & 398.19 & 0.0000 \\
FO & 456.41 & 0.0000 & FO & 456.41 & 0.0000 \\
OC5 & 573.36 & 0.0000 & OC5 & 573.36 & 0.0000 \\
OC10 & 602.92 & 0.0000 & OC10 & 602.92 & 0.0000
\end{tabular}

Ho: All panels contain unit roots, Ha: At least one panel is stationary. The $p$-value (Inverse chi-squared) represents that null hypothesis is rejected in all cases and panel contains no unit-root. * Fisher-type unit-root test is used because of the unbalanced panel data structure and it also considers the cross-section dependence in panel data. 


\section{References}

Admati, Anat R., Peter M. Demarzo, Martin F. Hellwig, and Paul Pfleiderer. 2018. The Leverage Ratchet Effect. Journal of Finance 73: 145-98. [CrossRef]

Allen, Franklin, Krzysztof Jackowicz, Oskar Kowalewski, and Łukasz Kozłowski. 2017. Bank lending, crises, and changing ownership structure in Central and Eastern European countries. Journal of Corporate Finance 42: 494-515. [CrossRef]

Arellano, Manuel, and Stephen Bond. 1991. Some Tests of Specification for Panel Data: Monte Carlo Evidence and an Application to Employment Equations. Review of Economic Studies 58: 277-97. [CrossRef]

Aysan, Ahmet F., Mustafa Disli, and Huseyin Ozturk. 2017. Bank lending channel in a dual banking system: Why are Islamic banks so responsive? The World Economy 41: 674-98. [CrossRef]

Barry, Thierno Amadou, Laetitia Lepetit, and Amine Tarazi. 2011. Ownership structure and risk in publicly held and privately owned banks. Journal of Banking $\mathcal{E}$ Finance 35: 1327-40.

Barry, Thierno Amadou, Laetiti Lepetita, and Frank Strobel. 2016. Bank ownership structure, lending corruption and the regulatory environment. Journal of Comparative Economics 44: 732-51. [CrossRef]

Berger, Allen, and Christa Bouwman. 2009. Bank Liquidity Creation. Review of Financial Studies 22: 3779-837. [CrossRef]

Berger, Allen, and John Sedunov. 2017. Bank liquidity creation and real economic output. Journal of Banking and Finance 81: 1-19. [CrossRef]

Berrospide, Jose M., and Rochelle M. Edge. 2010. The effects of bank capital on lending: What do we know? And, what does it mean? International Journal of Central Banking 6: 5-54.

Bonin, John P., Iftekhar Hasan, and Paul Wachtel. 2005. Privatization matters: Bank efficiency in transition countries. Journal of Banking \& Finance 29: 2155-78.

Carlson, Mark, Hui Shan, and Missaka Warusawitharana. 2013. Capital ratios and bank lending: A matched bank approach. Journal of Financial Intermediation 22: 663-87. [CrossRef]

Clarke, Shelley C., Murdoch K. McAllister, E. J. Milner-Gulland, G. P. Kirkwood Catherine, G. J. Michielsens, David J. Agnew, Ellen K. Pikitch, Hideki Nakano, and Mahmood S. Shivji. 2006. Global estimates of shark catches using trade records from commercial markets. Ecology Letters 9. [CrossRef] [PubMed]

Coleman, Nicholas, and Leo Feler. 2015. Bank ownership, lending, and local economic performance during the 2008-2009 financial crisis. Journal of Monetary Economics 71: 50-66. [CrossRef] [PubMed]

Cornett, Marcia Millon, Jamie John McNuttb, Philip E. Strahan, and Hassan Tehranian. 2011. Liquidity risk management and credit supply in the financial crisis. Journal of Financial Economics 101: 297-312. [CrossRef]

Cull, Robert, and Maria Martinez Peria. 2013. Bank ownership and lending patterns during the 2008-2009 financial crisis: Evidence from Latin America and Eastern Europe. Journal of Banking E Finance 37: 4861-78.

Dwarkasing, Mintra, Narly Dwarkasing, and Steven Ongena. 2017. The Bank Lending Channel of Monetary Policy: A Review of the Literature and an Agenda for Future Research, The Palgrave Handbook of European Banking. London: Palgrave Macmillan.

Fang, Xiang, David Jutrsa, Maria Soledad Martinez Peria, Andrea Presbitero, Lev Ratnovski, and Felix Vardy. 2018. The Effects of Higher Bank Capital Requirements on Credit in Peru. IMF Working Paper. Washington, DC, USA: IMF.

Fries, Steven, and Anita Taci. 2005. Cost efficiency of banks in transition: Evidence from 289 banks in 15 post-communist countries. Journal of Banking E Finance 29: 55-81.

Gambacorta, Leonardo, and David Marques-Ibanez. 2011. The Bank Lending Channel: Lessons from the Crisis. BIS Working Papers No. 345. Basel, Switzerland: BIS.

Gambacorta, Leonardo, and Paolo Emilio Mistrulli. 2004. Does bank capital affect lending behavior? Journal of Financial Intermediation 13: 436-57. [CrossRef]

Gorton, Gary B., and Richard Rosen. 1995. Corporate Control, Portfolio Choice, and the Decline of Banking. Journal of Finance 50: 1377-420. [CrossRef]

Haas, Ralph De, Yevgeniya Korniyenko, Alexander Pivovarsky, and Teodora Tsankova. 2015. Taming the herd? Foreign banks, the Vienna Initiative and crisis transmission. Journal of Financial Intermediation 24: 325-55. [CrossRef]

Hamada, Miki. 2017. Bank Capital and Bank Lending in the Indonesian Banking Sector. IDE Discussion Paper. Brighton: Development Studies Center, Institute of Developing Economies. 
Hanck, Christoph, Martin Arnold, Alexander Gerber, and Martin Schmelzer. 2019. Introduction to Econometrics with R. Essen: University of Duisburg-Essen.

Heryán, Tomáš, and Panayiotis G. Tzeremes. 2017. The bank lending channel of monetary policy in EU countries during the global financial crisis. Economic Modelling 67: 10-22. [CrossRef]

Heuvel, Skander J. Van den. 2002. Does Bank Capital Matter for Monetary Transmission? FRBNY Economic Policy Review 8: 259-65.

Ivashina, Victoria, and David Scharfstein. 2010. Bank lending during the financial crisis of 2008. Journal of Financial Economics 97: 319-38. [CrossRef]

Kashyap, Anil K., and Jeremy C. Stein. 2000. What Do a Million Observations on Banks Say about the Transmission of Monitory Policy. American Economic Review 90: 407-28. [CrossRef]

Kim, Dohan, and Wook Sohn. 2017. The effect of bank capital on lending: Does liquidity matter? Journal of Banking and Finance 77: 95-107. [CrossRef]

Kishan, Ruby P, and Timothy Opiela. 2000. Bank Size, Bank Capital, and the Bank Lending Channel. Journal of Money, Credit and Banking 32: 121-41. [CrossRef]

Labra, Romilio, and Celia Torrecillas. 2018. Estimating dynamic Panel data. A practical approach to perform long panels. Revista Colombiana de Estadística 41: 31-52. [CrossRef]

Majcher, Peter. 2015. Increased Bank Capital Requirements: Neither Panacea nor Poison. Procedia Economics and Finance 25: 249-55. [CrossRef]

Mileva, Elitz. 2007. Using Arellano-Bond Dynamic Panel GMM Estimators in Stata. New York: Fordham University.

Nicolò, Gianni De. 2015. Revisiting the Impact of Bank Capital Requirements on Lending and Real Activity. IMF Working Paper Series; Washington, DC: International Monetary Fund and CESifo.

Plosser, Matthew C., and João A. C. Santos. 2018. The Cost of Bank Regulatory Capital. Staff Reports. New York: Federal Reserve Bank of New York.

Roodman, David. 2009. A note on the theme of too many instruments. Oxford Bulletin of Economics and Statistics 71: 135-58. [CrossRef]

Salachas, Evangelos N., Nikiforos T. Laopodis, and Georgios P. Kouretas. 2017. The bank-lending channel and monetary policy during pre- and post-2007 crisis. Journal of International Financial Markets, Institutions and Money 47: 176-87. [CrossRef]

Sheng, Andrew. 2013. Asian Banking: Moving Beyond Basel III. Fung Global Institute No. 07 (Nov). Lung Fu Shan: Fung Global Institute.

Tanda, Alessandra. 2015. The Effects of Bank Regulation on the Relationship Between Capital and Risk. Comparative Economic Studies 57: 31-54. [CrossRef]

Wooldridge, Jeffrey M. 2013. Introductory Econometrics: A Modern Approach, 5th ed.Boston: Cengage Learning.

Xiong, Qiyue. 2013. The Role of the Bank Lending Channel and Impacts of Stricter Capital Requirements on the Chinese Banking Industry. BOFIT Discussion Papers. Helsinki: Bank of Finland, BOFIT Institute for Economies in Transition.

(C) 2019 by the authors. Licensee MDPI, Basel, Switzerland. This article is an open access article distributed under the terms and conditions of the Creative Commons Attribution (CC BY) license (http://creativecommons.org/licenses/by/4.0/). 